\title{
SOME SIGNIFICANT EXTERIOR AND REPRODUCTIVE PROPERTIES OF THE ENGLISH THOROUGHBRED HORSE POPULATION FROM THE STUD FARM "LJUBICEVO" - SERBIA
}

\author{
V. Đermanović ${ }^{1}$, S. Mitrović ${ }^{1}$, N. Đordjević ${ }^{2}$, M. Novaković ${ }^{3}$ \\ ${ }^{1}$ Faculty of Agriculture, University of Belgrade, Nemanjina 6, 11080, Belgrade-Zemun, Republic of \\ Serbia \\ ${ }^{2}$ NGO Agro-projekt Timok, Zaječar, Republic of Serbia \\ ${ }^{3}$ Ministry of Agriculture, Forestry and Waterpower Engineering, Nemanjina 22-24, 11000, Belgrade, \\ Republic of Serbia \\ Corresponding author: djermanovic@agrif.bg.ac.rs \\ Original scientific paper
}

Abstract: The investigation included 5 stallions (average age of 10.40 years) and 33 mares (average age of 10.33 years) with pedigree of the English Thoroughbred horse breed that are used for breeding on the Stud Farm Ljubicevo Serbia. The investigation of some significant properties relating to the exterior (at stallions) and reproductive ones (at mares) were carried out in the year 2009. The following average exterior (body) measures of the stallions: the body mass (474.80 $\mathrm{kg}$ ), withers height $(160.46 \mathrm{~cm})$, trunk or body length $(161.88 \mathrm{~cm})$, breast circumference $(187.96 \mathrm{~cm})$ and tibia circumference $(19.22 \mathrm{~cm})$ were within the standards of this horse breed of the age. The gestation period at mares, regardless the sex of a colt, averagely lasted 337.70 days. With the mares having had a male colt, the gestation lasted a little bit longer (338.92 days) than with the mares having had female colts (336.90 days). The difference in the gestation duration (2.02 days) was not statistically significant $(\mathrm{P}>0.05)$. Between the age of the mares and the gestation duration (regardless the sex of a colt) it was found a positive slight correlation $\left(r_{p}=0.320\right)$. Furthermore, between the age of the mares and the gestation duration it was found medium $\left(\mathrm{r}_{\mathrm{p}}=0.453\right)$ correlation at male colts, and quite poor correlation $\left(r_{p}=0.202\right)$ at female colts. Found coefficients of the phenotype correlation were not statistically confirmed $(\mathrm{P}>0.05)$. correlation.

Key words: English thoroughbred horse, exterior measures, gestation, 


\section{Introduction}

The English thoroughbred horse is a horse breed of universal abilities for sport which, at the very beginning of the breed creation, that is, of the breedingselection work, late in 17th and early in 18th century in Great Britain, it was paid special attention to, particularly to acquiring as much as possible greater speed in gallop. The result of the before-mentioned is, among other things, the beginning of a new era in the world sport horse growing and defining competition, by which horse-racing became a profitable business (Broome, 1998; Mitrovic and Grubic, 2003; Mitchell and Leimbach, 2004). Besides gallop races, the English throughbred horse is also used in hurdle races and training competitions, hunting horse-riding, then for recreation, primarily the horses of preety weak sport quality or of those with emphasized desired movements and walk in other events of horseriding (Crook, 1997).

Today the English thoroughbred horse is grown worldwide, overcoming thus geographic, politic and racial barriers, as well as the frontiers between states, although there are still relativelly few sources of data on the spread of the whole world population of the English thoroughbred horse (Kidd, 1995).

The English thoroughbred horse has had a relatively long tradition of being grown both in Serbia and in the surrounding countries. In Serbia it is grown in a relatively small number of stud farms and some horse clubs (Mitrovic et al., 2004), the number of which has been stagnating in the last few years, while in some surrounding countries it has been increasing, as it is in Croatia (Korabi et al., 2007). Besides that, Trailovic et al. (2007) have observed that the interest of the public in our country (similarly as it is in the world) is directed to the horse races, horse riding and recreation, that is, the initiative of the individuals in the private sector is mainly concentrated on breeding horses for the before-mentioned purposes. That is why in urban areas people breed the English thouroughbred horses, trotters and half-breeds and types of horses. One of the stud farms in Serbia having a considerable number of the English thoroughbred horses of various categories is the Public Enterprise Ljubicevo - the Stud Farm "Ljubicevo".

The exsterior, reproductive properties, and even racing capacities of the English thoroughbred horses in the Republic of Serbia have been slightly researched and determined. As early as in the middle of 20th century, Hrasnica et al. (1964) declare found exterior parameters of the English thoroughbred horse: withers height $-159.2 \mathrm{~cm}(+)$ and $160.3 \mathrm{~cm}\left({ }^{\Uparrow}\right)$; the trunk length $-161.0 \mathrm{~cm}($ ( $)$

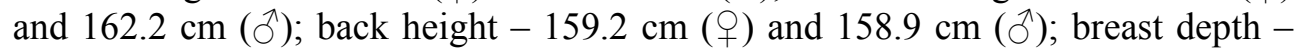
$76.7 \mathrm{~cm} \mathrm{(}($ + $)$ and $75.2 \mathrm{~cm}\left({ }^{\top}\right)$; breast circumference $-185.4 \mathrm{~cm}(+)$ and $182.4 \mathrm{~cm}$ (ठ); tibia circumference $-19.0 \mathrm{~cm}($ (†) and $20.3 \mathrm{~cm}($ ( ); body mass $-512.5 \mathrm{~kg}$ (ठ). Mitrovic and Grubic (2003) state that the English thoroughbred horse belongs to a group of light horses whose body mass ranges from 455 and $555 \mathrm{~kg}$, the 
withers height 155 and $175 \mathrm{~cm}$, while the gestation period is between 328 and 340 days. Body weight of the horse sports towards Bilal and Meral (2000) is between 350 and $500 \mathrm{~kg}$.

However, it should be taken into considertaion that the body measures and reproductive properies of all domestic animals, including horses, as well, besides the genotype, depend on a considerable number of paragenetic factors - the accomodation conditions, nourishment, season, etc. Therefore, Cilek (2009), Davies-Morel et al. (2002), Hintz et al. (1979, 1992), Hevia et al. (1994), Kurtz Filho et al. (1997) and Sánchez (1998) conclude that the duration of gestation depends on the age of a mare, the season in which mating and foaling occur, sex of a colt, conditions of breeding, and quality of nourishment.

That is why the basic aim of this study was to analyze the exterior (the body measures and indexes of body growth) and reproductive (the fertility, duration of gestation, phenotype correlation) properties of the English thoroughbred horse (the best breed for gallop races) grown on the Stud Farm "Ljubicevo", as well as the possibilities of offering strategies for further improvement and development of breeding this horse breed, including also horse breeding for sport (primarily gallop races) in the Republic of Serbia. Moreover, by defining the phenotype correlation coefficient, it is emphasized the influence of the age of mares and the sex of a colt on the duration of gestation.

\section{Materials and Methods}

The research was carried out in the year 2009 at the Stud Farm "Ljubicevo" Public Enterprise Ljubicevo. This stud farm has been existed for over 150 years; a few years after it had been founded, there were more than 500 heads of purebred horses of Arab and English breeds (Mitrovic and Grubic, 2003). During the First and Second World Wars the stud farm was devastated, so that at the end of the Second World War there were only 83 heads there (60 heads of Arab horses and 23 heads of the English thoroughbred horses). Today, at the Stud Farm "Ljubičevo" it is being bred exclusivelly the English thoroughbred horse. The greatest success at this stud farm was attained by the heads "Ljubicevac" (father "Faktor", mother "Ljubicevka") and "Tina". The former in 1974 and the latter in 1995 won the "Tripla kruna".

The research included 5 stallions and 33 breeding mares who, having been actively used in mating with acknowledged origin heads, already gave offspring during this year.

The following body measures were taken of the stallions of the age between 7 and 17: the withers height, trunk length, breast circuference, tibia circumference, as well as the body mass. For the mentioned parameters, it was calculated the absolute and relative measures of variations, then some significant indexes of body 
growth of the stallions, such as: format index - circumference (trunk length/withers heigth) $\mathrm{x} 100$, trunk compactness index (breast range/trunk length) $\mathrm{x} 100$, massiveness (breast circumference/withers height) x 100, body mass index (body mass/withers height) x 100 and bone index (tibia circumference/withers height) $\mathrm{x}$ 100.

At breeding mares of the age between 5 and 17, it was also calculated the absolute and relative measures of variations for the age of mares, duration of gestation, and it was determined the significance of differences among the mares, depending on the sex of a colt. Besides that, it was determined the number of colts per a mare since the first conception up to the year 2009, when the data for this research were taken. On the basis of the age of mares and the sex of a colt, and by calculating the phenotype correlation coefficient $\left(r_{p}\right)$, it was determined how much the correlation between the age and duration of gestation is strong.

\section{Results and Discussion}

The total number of registered heads at the Stud Farm "Ljubicevo" in 2009 was 122 , out of which, in the category of breeding stallions, there were 6 heads (4.92\%), breeding mares $-51(41.80 \%)$, heads for competition $-12(9.84 \%)$, colts and offspring $-53(43.44 \%)$.

At the mentioned stud farm 5 stallions are used for breeding, while one stallion is, because of its age, (24 years) out of use for breeding. The average age of the stallions being used in breeding was about 10 years, and their average values and variety of exterier properties are shown in Table 1.

Table 1. Average values and variety of exterior properties and body growth index of the stallions

\begin{tabular}{|l|c|c|c|c|}
\hline \multicolumn{5}{|c|}{ Age ,body mass and exterior measures } \\
\hline Indexes & $\mathrm{X}$ & $\mathrm{Sx}$ & $\mathrm{S}$ & $\mathrm{C} . \mathrm{V}$. \\
\hline Age (years) & 10.40 & 1.54 & 3.44 & 33.08 \\
\hline Body mass (kg) & 474.80 & 11.98 & 26.79 & 5.64 \\
\hline Withers height (cm) & 160.46 & 0.81 & 1.81 & 1.13 \\
\hline Trunk length (cm) & 161.88 & 0.87 & 1.94 & 1.20 \\
\hline Breast circumference (cm) & 187.96 & 1.45 & 3.24 & 1.72 \\
\hline Tibia circumference (cm) & 19.22 & 0.07 & 0.15 & 0.78 \\
\hline \multicolumn{5}{|l|}{ Body growth indexes } \\
\hline Indexes & $\mathrm{X}$ & $\mathrm{Sx}$ & $\mathrm{S}$ & $\mathrm{C} . \mathrm{V}$. \\
\hline Format (frame) index & 100.88 & 0.09 & 0.20 & 0.20 \\
\hline Trunk compactness index & 116.13 & 1.19 & 2.67 & 2.30 \\
\hline Massiveness Index & 117.16 & 1.19 & 2.67 & 2.28 \\
\hline Body mass index & 296.03 & 8.33 & 18.63 & 6.29 \\
\hline Bone index & 11.98 & 0.09 & 0.21 & 1.75 \\
\hline
\end{tabular}


It is evident from the Table 1 that the average body mass of stallion amounted $474.80 \mathrm{~kg}$, and that the variation coefficient was rather low $(5.64 \%)$, in comparison with the age of stallions used for breeding, whose variation coefficient amounted $33.08 \%$; the fact quite reasonable since the youngest stallion was 7 years old, while the oldest one was 17 . The withers height was $160.46 \mathrm{~cm}$, trunk length $161.88 \mathrm{~cm}$, breast circumference $187.96 \mathrm{~cm}$, and tibia circumference $19.22 \mathrm{~cm}$. Regardless the heterogenity referring to the age of stallions, their exterior measures were rather equal, the fact proved by the found variation coefficients.

In comparison to the exterior measures of the stallion of the English thoroughbred horse determined by Hrasnica et al. (1964), Bilal and Meral (2000) and Mitrovic and Grubic (2003), it can be concluded that their data are quite similar to ours, that is, the English thouroughbred horse belong to a group of lighter horses of harmonious body structure (sport-like), the fact proved by calculated body growth indexes.

In 2009, out of 51 mares, 33 ones had normal conception and gestation, and gave birth to healthy offspring. Since the breeding period up to these days, the mares included in the research, (33) of various age had total of 124 colts of both sexes ( 3.76 colts per a mare).

The following table (Table 2) shows the average age structure and getstaion duration of 33 breeding mares included in the research depending on the sex of colts.

Table 2. Average values and age variability of the mares (in years) and gestation duration (number of days) and significance of differences depending on the colt sex

\begin{tabular}{|c|c|c|c|c|c|}
\hline \multicolumn{6}{|c|}{ Average values and variation } \\
\hline Indexes & $\mathrm{n}$ & $\mathrm{X}$ & Sx & $\mathrm{S}$ & C.V. \\
\hline Age of mares with $\bigcirc$ colt & 20 & 10.05 & 0.70 & 3.14 & 31.24 \\
\hline Age of mares with $\hat{\sigma}$ colt & 13 & 10.77 & 0.97 & 3.49 & 32.40 \\
\hline Age of mares with $q+\hat{o}$ colts & 33 & 10.33 & 0.57 & 3.30 & 31.95 \\
\hline Gestation of mares with $P$ colt & 20 & 336.90 & 1.80 & 8.04 & 2.39 \\
\hline Gestation of mares with $\hat{\mathrm{c}}$ colt & 13 & 338.92 & 2.38 & 8.60 & 2.54 \\
\hline Gestation of mares with $q+\hat{\partial}$ colts & 33 & 337.70 & 1.45 & 8.32 & 2.46 \\
\hline \multicolumn{6}{|c|}{ Significance of differences } \\
\hline Indexes & $\mathrm{X}_{\mathrm{o}}$ & $\mathrm{X}_{0}$ & $\mathrm{~d}$ & $t_{\text {exp. }}$ & $\mathrm{t}_{\mathrm{tab}}$ \\
\hline Age of mares & 10.05 & 10.77 & $0.72^{\mathrm{ns}}$ & 0.616 & 2.042 \\
\hline Gestation duration & 336.90 & 338.92 & $2.02^{\mathrm{ns}}$ & 0.769 & 2.042 \\
\hline
\end{tabular}

The data given in the Table 2 show that the average age of the mares, regardless the sex of a colt, was similar to the age of the stallions, and amounted 10.33 years $(0$ colts $=10.77$; $q$ colts $=10.05)$; the deviations from the average age (C.V. $=31.95 \%$ ) were also similar to the age of the stallions. Moreover, the gestation duration at mares giving birth to male colts in comparison to the mares who had female colts was averagely longer for 2.02 days (338.92 - 336.90 days), 
while at all mares, regardless the colt, it lasted 337.70 days. The found difference in gestation duration (2.02 days) was not statistically significant $(\mathrm{P}>0,005)$. The variabilities referring to the gestation duration were insignificant since the value of the variation coefficient amounted about $2.50 \%$.

Similar investigation was carried out by Valera et al. (2006) with two horse breeds, out of which one was Arab purebred horse. At the mares of the age between 10 and 12, the authors found out that the gestation of the mares having male colts in comparison to the ones having female colts lasts longer for 1.41 day (341.05 - 339.64 days), and that the variability relating to the duration is quite low (C.V. $-2.87 \%$ and $2.82 \%$ ).

Most of cited authors, on the basis of their investigations, quote that the age of a mare (mother) has a certain influence on the gestation duration at various horse breeds, that is, the duration of the first gestation shortens progressively to a certain age, and then it becomes longer. In our investigation we have also come to similar conclusions based on the calculated phenotype correlation coefficients between the age of mares and the gestation duration (Table 3).

Table 3. Phenotype correlation coefficients $\left(r_{p}\right)$ between the age of mares (A.M.) and gestation duration (G.D.) depending on the sex of a colt

\begin{tabular}{|c|c|c|c|c|c|}
\hline Indexes & $\mathrm{n}$ & $\mathrm{r}_{\mathrm{xy}}$ & $\mathrm{t}_{\exp .}$ & $\mathrm{t}_{\text {tab. }}$ & Correlation meaning \\
\hline A.M. $x$ G.D. $(+)$ & 20 & $0.202^{\text {ns }}$ & 0.875 & 2.101 & Quite poor \\
\hline A.M. $x$ G.D. $\left(\bigcirc^{\lambda}\right)$ & 13 & $0.453^{\text {ns }}$ & 1.685 & 2.201 & Medium \\
\hline A.M. x G.D. $(++\overbrace{}^{\lambda})$ & 33 & $0.320^{\text {ns }}$ & 1.880 & 2.042 & Poor \\
\hline
\end{tabular}

The data from the Table 3 show that, between the ages of mares and gestation durations, depending on the sex of colts, it was found out quite poor $\left(r_{p}=0.202\right)$, medium $\left(r_{p}=0.453\right)$ and poor $\left(r_{p}=0.320\right)$ correlation. Found phenotype correlation coefficients are not statistically significant $(\mathrm{P}>0.05)$.

\section{Conclusion}

On the basis of the carried out investigations aimed to determine some important exterior and reproductive properties of the English thoroughbred horse population grown on the Stud Farm "Ljubicevo" (Serbia), it can be concluded that the body measures of the examined stallions are in accordance with the standards of the breed, as well the age of the mares and the sex of a colt has the influence on the gestation duration. If it is observed more broad, it can be concluded that the gestation duration, with some oscilations, increases with the age of a mare (mother), as well as that the male colts in comparison to female colts cause the gestation duration to become longer. 


\title{
Važnija eksterijerna i reproduktivna svojstva populacije engleskog punokrvnog konja gajenog na ergeli "Ljubičevo" - Srbija
}

\author{
V. Đermanović, S. Mitrović, N. Đorđević, M. Novaković
}

\section{Rezime}

Istraživanjima je obuhvaćeno 5 pastuva (prosečne starosti 10,40 godina) i 33 kobile (prosečne starosti 10,33 godina) sa poznatim poreklom (pedigreom) engleske punokrvne rase konja koja se na ergeli Ljubičevo - Srbija aktivno koriste u priplodu. Utvrđivanja važnijih eksterijernih (pastuvi), odnosno reproduktivnih svojstava (kobile) sprovedena su u 2009. godini.

Utvrđene prosečne eksterijerne (telesne) mere pastuva: telesna masa $(474,80$ $\mathrm{kg}$ ), visina grebena $(160,46 \mathrm{~cm})$, dužina trupa - tela $(161,88 \mathrm{~cm})$, obim grudi $(187,96 \mathrm{~cm})$ i obim cevanice $(19,22 \mathrm{~cm})$ su bile u okviru standarda ove rase konja u odgovarajućoj starosnoj dobi.

Bremenitost (gestacija) kobila, bez obzira na pol ždrebeta, u proseku je trajala 337,70 dana. Kod kobila koje su oždrebile mušku ždrebad bremenitost je trajala nešto duže (338,92 dana), nego kod kobila koje su oždrebile žensku ždrebad (336,90 dana). Razlika u trajanju bremenitosti (2,02 dana) nije bila statistički signifikantna $(\mathrm{P}>0,05)$. Između starosti kobila i trajanja bremenitosti (bez obzira na pol ždrebeta) utvrđena je pozitivna slaba korelaciona povezanost $\left(r_{p}=0,320\right)$. Zatim, između starosti kobila i trajanja bremenitosti utvrđena je srednja $\left(\mathrm{r}_{\mathrm{p}}=0,453\right)$ korelaciona povezanost kod muške ždrebadi, odnosno jako slaba $\left(r_{p}=0,202\right)$ kod ženske ždrebadi. Utvrđeni koeficijenti fenotipske korelacije nisu bili statistički potvrđeni $(\mathrm{P}>0,05)$.

\section{References}

BILAL T., MERAL Y. (2000): Determination of the Association Between Heart Diameter and Myocardial Thickness with Body Weights in English Racing Horses by M-mode Echocardiography. Turk. J. Vet. Anim. Sci., 24, 571-576.

BROOME D. (1998): Encyclopedia of the horse. Bounty Books. Octopus Publishing Group, London.

CILEK S. (2009): The survey of reproductive success in Arabian horse breeding from 1976-2007 at Anadolu State Farm in Turkey. Journal of Animal and Veterinary Advances, 8, 2, 389-396. 
CROOK L. (1997): Encyclopedia of the horse. Greenwitc Edition. Bibliophile House, London.

DAVIES-MOREL D.M.C., NEWCOMBE J.R., HOLLAND S.J. (2002): Factors affecting gestation length in the thoroughbred mare. Anim. Reprod. Sci., 74, 175-185. HEVIA M.L., QUILES A.J., FUENTES F., GONZALO C. (1994): Reproductive performance of thoroughbred mares in Spain. J. Equine Vet. Sci., 53, suppl. 1, 295. HINTZ H.F., HINTZ R.L., LEIN D.H., Van VLECK L.D. (1979): Lenght of gestation periods in Thoroughbred mares. J. Equide Med., 3, 289-292.

HINTZ H.F., WILLIAMS J., HILLMAN R., HOUSAY H., FERRER R. (1992): Effect of month of breeding on duration of gestation period of Thoroughbred. Equine Pract., 14, 16-20.

HRASNICA F., ILANCIC D., MILOSAVLJEVIC S., PAVLOVIC S., RAKO A., SMALCELJ I. (1964): Special Animal Husbandry (second edition). Department for the issuance of textbooks of the Socialist Republic of Serbia, Belgrade.

KIDD J. (1995): The Horse, the complete guide to horse breeds and breeding. Tiger Books International PLC.

KURTZ FILHO M., DEPRÁ N.M., ALDA J.L., CASTRO I.N., de la CORTE F.D., SILVA J.H.S., SILVA C.A.M. (1997): Duracao da gestacao em relacao a idade de éguas da raca Puro Sangue de Corrida, aos pesos do potro e da placenta, e ao horario do parto. Braz. J. Vet. Res. Anim. Sci., Sao Paulo 34, 1, 37-40.

KORABI N., CURIK I., CACIC M. (2007): Analysis of Thoroughbred breeding in Croatia. 42. Croatia and $2^{\text {st }}$ International Symposium on Agriculture, Opatija.

MITCHELL F., LEIMBACH J. (2004): Racehorse breeding theories. The Russell Meerdink Company Ltd. Wisconsin.

MITROVIC S., GRUBIC G. (2003): Breeding and feeding of horses. Faculty of Agriculture, University of Belgrade, Belgrade.

MITROVIC S., ZIVOTIC V., ILIC P. (2004): The possibilities of improving breeding of horses. Proceedings of research papers, 10, 2, 95-100.

SÁNCHEZ A. (1998): Contribución al estudio de la duración de la gestación y su relación con el rendimiento en el producto equino Fina Sangre de Carrera. Tesis Magister en Ciencias. Universidad Austral de Chile.

TRAILOVIC D., PETRUJKIC T., VUCINIC M., TRAILOVIC R., KATRINIC Z. (2007): Contemporary trends in health care and breeding of horses. University of Belgrade - Faculty of Veterinary Medicine and the Ministry of Agriculture, Forestry and Water Management of Republic of Serbia, Veterinary Directorate, Belgrade.

VALERA M., BLESA F., Dos SANTOS R., MOLINA A. (2006): Genetic study of gestation length in andalusian and arabian mares. Animal Reproduction Science 95, 75-96. 